\title{
Potensi Pengembangan Industri Biomassa Wood Pellet di Indonesia dengan Analisis BCG dan SWOT
}

\author{
Santika Sari ${ }^{* 1}$, Claudia Ivana Sitorus ${ }^{1}$ \\ 1) Program Studi Teknik Industri, Fakultas Teknik, Universitas Pembangunan Nasional Veteran Jakarta \\ Jl. RS. Fatmawati Raya, Pd. Labu, Kec. Cilandak, Daerah Khusus Ibukota Jakarta 12450, Indonesia \\ Email: santika.sarl@upnvj.ac.id"; claudia.ivanas@upnvj.ac.id
}

\begin{abstract}
ABSTRAK
Kebutuhan energi di Indonesia cenderung mengalami peningkatan dari tahun ke tahun dikarenakan adanya pertumbuhan jumlah penduduk dan juga peningkatan pertumbuhan ekonomi. Hal ini menjadi tantangan bagi keamanan energi nasional agar dapat mengimbangi jumlah pasokan dengan jumlah permintaan (diperkirakan permintaan pada tahun 2035 akan menjadi tiga kali lipat lebih tinggi daripada jumlah permintaan sekarang). Biomassa merupakan bahan bakar ramah lingkungan yang dapat dimanfaatkan sebagai pengganti bahan bakar fosil untuk mengurangi pemanasan global. Indonesia diyakini berpotensi untuk menjadi salah satu negara pemain utama industri pelet kayu dunia. Namun, produksi pelet kayu Indonesia hingga saat ini masih dapat dikatakan relatif kecil, yakni sekitar 80.000 ton per tahun. Oleh sebab itu, hal tersebut penting untuk digali lebih dalam. Untuk menganalisa potensi-potensi terkait dengan Industri Biomassa Wood Pellet di Indonesia, dapat digunakan dua metode, yaitu analisis BCG dan juga analisis SWOT. Dari analisis BCG, diperoleh bahwa Indonesia berada pada posisi Question Mark untuk industri wood pellet, dengan nilai tingkat pertumbuhan pasar, dan pangsa pasar relatif secara berurutan sebesar $87,2270943 \%$ dan 0,087564003 . Dengan demikian, Strategi SWOT yang paling cocok untuk diterapkan pada posisi Question Mark adalah strategi SO (Strength-Opportunity), yaitu; memaksimalkan sumber daya alam yang dimiliki, dari mulai ketersediaan lahan serta ketersediaan tanaman yang ada untuk memenuhi energi nasional serta pasar internasional, serta mendukung kebijakan protokol Paris, sehingga dapat menjalin kerja sama dengan negara-negara lain yang memiliki visi yang sama.
\end{abstract}

Kata Kunci: Biomassa, Pelet Kayu, Analisis BCG, dan Analisis SWOT

\begin{abstract}
Energy needs in Indonesia tend to increase from year to year due to population growth and economic growth. This is a challenge for national energy security to be able to balance the amount of supply with the amount of demand (it is estimated that demand in 2035 will be three times higher than the current demand). Biomass is an environmentally friendly fuel that can be used as a substitute for fossil fuels to reduce global warming. Indonesia is believed to have the potential to become one of the main players in the world wood pellet industry. However, Indonesia's wood pellet production is still relatively small, which is around 80,000 tons per year. Therefore, it is important to dig deeper. To analyze the potentials associated with the Wood Pellet Biomass Industry in Indonesia, two methods can be used, namely BCG analysis and SWOT analysis. From the BCG analysis, it is found that Indonesia is in the Question Mark position for the wood pellet industry, with the value of market growth rate, and relative market share of $87.2270943 \%$ and 0.08756403 respectively. Thus, the most suitable SWOT strategy to be applied to the Question Mark position is the SO (StrengthOpportunity) strategy, namely; maximizing the natural resources owned, starting from the availability of land and the availability of existing plants to meet national energy and international markets, as well as supporting the Paris protocol policy.
\end{abstract}

Keywords: Biomass, Wood Pellet, BCG Analysis, and SWOT Analysis.

\section{Pendahuluan}

Kebutuhan energi di Indonesia cenderung mengalami peningkatan dari tahun ke tahun dikarenakan adanya pertumbuhan jumlah penduduk dan juga peningkatan pertumbuhan ekonomi. Hal ini menjadi tantangan bagi keamanan energi nasional agar dapat mengimbangi jumlah pasokan dengan jumlah permintaan (diperkirakan permintaan pada tahun 2035 akan menjadi tiga kali lipat lebih tinggi daripada jumlah permintaan sekarang). Pengembangan-pengembangan perlu dilakukan untuk meningkatkan ketersediaan pasokan energi nasional 
sekarang dan di waktu yang akan datang. Energi fosil yang tersedia semakin menipis yang mengakibatkan kenaikan harga jual bahan bakar fosil. Selain itu, energi fosil seperti batubara, gas, dan minyak bumi akan melepaskan karbon dioksida (CO2) ketika dibakar. Pelepasan sejumlah besar karbon dioksida ke atmosfer merupakan salah satu penyebab utama terjadinya pemanasan global (efek rumah kaca / green house gas emission- GHG). Menurut Yilmaz dan Selim (2013), saat ini peningkatan produksi karbon dioksida (CO2) di dunia telah meningkat sebanyak 24 juta ton/tahun, dari 4 juta ton/tahun menjadi 28 juta ton/tahun. Hal ini mengakibatkan kesadaran dan perhatian masyarakat dunia, tidak hanya Indonesia, menjadi lebih tinggi untuk menggunakan bahan bakar yang ramah lingkungan.

Biomassa merupakan bahan bakar berbiaya produksi rendah dan ramah lingkungan, yang dapat dimanfaatkan menjadi pengganti bahan bakar fosil untuk mengurangi pemanasan global (Qian et al, 2011; Chou et al, 2009). Kayu adalah salah satu contoh biomassa yang apabila dikelola secara berkelanjutan, tidak akan menambahkan emisi karbon ekstra ke atmosfer. Kayu bebas dari sulfur dan bahan-bahan yang bersifat korosif dan polutif (Walker 2006). Menurut Setiawan (2007), keuntungan penggunaan biomassa menjadi sumber energi adalah dapat mengurangi jumlah karbon dioksida yang terdapat di atmosfer. Hal tersebut dapat terjadi karena gas hasil pembakaran yang dihasilkan lebih sedikit, sehingga tumbuhan dapat menyerapnya kembali (bersifat karbon netral). Banyak ahli sepakat bahwa selain kayu, biomassa yang berasal dari tumbuhan lain pun juga memiliki prinsip yang sama. Jerman, Swedia, Denmark, Amerika Serikat, China, Vietnam dan Korea Selatan, adalah contoh dari negara-negara pemain utama dari industri pelet kayu dunia.

Indonesia diyakini berpotensi untuk menjadi salah satu negara pemain utama industri pelet kayu dunia. Hal ini disebabkan Indonesia didukung oleh curah hujan yang tinggi, tanah yang subur, iklim tropis, ketersediaan kawasan hutan industri dan perkebunan yang mencakup kurang lebih 80 juta hektar (dapat digunakan untuk hutan tanaman energi), serta letak geografis yang berdekatan dengan Korea Selatan, Vietnam, dan China. Indonesia juga telah dikenal di dunia sebagai produsen minyak kelapa sawit terbesar dengan total produksi yang mampu mencapai hingga 23 juta ton/tahun. Limbah kayu hasil produksi minyak kelapa sawit ini juga dapat dimanfaatkan lebih jauh untuk produksi pelet kayu. Dengan potensi alam yang besar, produksi pelet kayu Indonesia hingga saat ini masih dapat dikatakan relatif kecil, yakni sekitar 80.000 ton per tahun. Produksi pelet kayu negara tetangga, Malaysia, mencapai lebih dari 180 ribu per tahun. Berdasarkan Peraturan Presiden RI Nomor 5 tahun 2006, target pemerintah Indonesia dalam hal penggunaan energi biomassa untuk mendukung kebutuhan energi nasional hanya sekitar $5 \%$ hingga pada tahun 2025 . Selain itu, produksi pelet kayu juga dapat dijadikan sebagai peluang ekspor, mengingat bahwa peningkatan konsumsi energi di dunia diperkirakan akan terjadi pada tahun 2035 (Roos, 2012).

Dengan berdasarkan pada kondisi-kondisi terkait industri biomassa pelet kayu yang telah disebutkan di atas, inilah yang membuat peneliti untuk membahas hal tersebut secara lebih mendalam dalam penelitian berjudul "Potensi Pengembangan Industri Biomassa Wood Pellet di Indonesia dengan Analisis BCG dan SWOT". Penelitian terdahulu yang dijadikan acuan dalam penelitian ini berasal dari sebuah jurnal dari Jurnal Ilmu Kehutanan 12 (2018) dengan judul “Kajian Peningkatan Potensi Ekspor Pelet Kayu Indonesia sebagai Sumber Energi Biomassa yang Terbarukan" karya Victor Tulus Pangapoi Sidabutar, yang membahas mengenai potensi Indonesia untuk menjadi salah satu produsen utama utama pelet kayu di ASEAN. Pada penelitian ini, penulis akan menggunakan metode analisis SWOT dan matriks BCG untuk menjelaskan fenomena-fenomena yang terjadi pada industri biomassa pelet kayu, dari mulai kekuatan (strength), kelemahan (weakness), peluang (opportunity), ancaman (threat), serta strategi yang sebaiknya diambil pada kondisi yang tengah terjadi terkait dengan industri biomassa pelet kayu di Indonesia, dengan tujuan penelitian sebagai berikut:

1. Mengetahui variabel kekuatan, kelemahan, peluang, dan ancaman pada industri biomassa wood pellet di Indonesia

2. Mengetahui posisi industri biomassa wood pellet di Indonesia pada matriks BCG

3. Merancang strategi yang baik untuk pengembangan industri biomassa wood pellet di Indonesia

Biomassa memiliki prinsip dasar dimana tanaman akan menggunakan air dan unsur hara yang terdapat di dalam tanah serta karbondioksida yang terdapat di atmosfer sehingga mampu menghasilkan bahan organik untuk memperkuat jaringan dan membentuk daun, bunga atau buah, untuk menyerap energi dari matahari melalui proses fotosintesis. $\mathrm{CO}_{2}$ akan dilepaskan ke atmosfer pada saat biomassa diubah menjadi energi. Apabila dilakukan perbandingan antara karbondioksida hasil pembakaran gas alam atau minyak bumi dengan hasil pembakaran biomassa, siklus $\mathrm{CO}_{2}$ ada biomassa akan menjadi lebih pendek. Hal ini mengindikasikan kesetimbangan $\mathrm{CO}_{2}$ di atmosfer tidak akan terganggu dikarenakan penggunaan biomassa. Terciptanya energi yang berkelanjutan merupakan hal yang dimanfaatkan sebagai kelebihan dari biomassa. 
Dalam proses manufaktur pelet kayu, telah digunakan mesin di tiap tahapannya sebagai teknologi pendukung dalam pembuatan pelet kayu itu sendiri. Secara garis besar pembuatan pelet kayu melalui tahapan sebagai berikut:

1. supply bahan baku ke pabrik

2. Penyeragaman ukuran partikel, kadar air, dan karakteristik bahan

3. Penghancuran biomassa (chiping and miling)

4. Pengeringan (drying)

5. Pencetakan pellet (pelleting)

6. Pendinginan dan penyimpanan (cooling)

7. Pengemasan

8. Distribusi

Gambar 1 menyajikan proses pembuatan pelet kayu di pabrik.

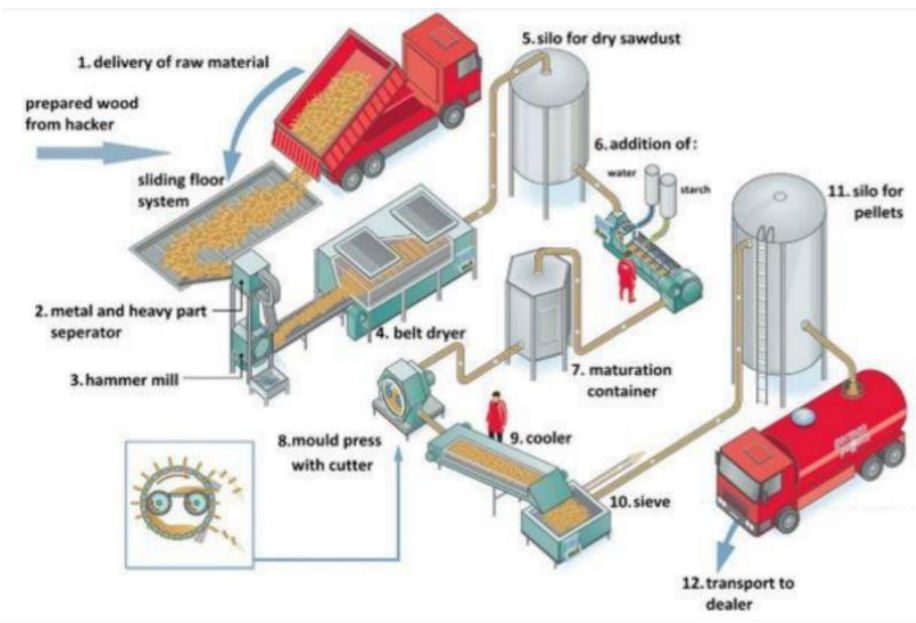

Sumber: E-book Pellet Kayu Energi Hijau Masa Depan karya Rudianto Amirta,2018

Gambar 1. Proses pembuatan pelet kayu

Hingga saat ini, produksi pelet kayu di Indonesia hanya sekitar 80.000 ton per tahun. Hal ini masih relatif kecil. Beberapa hal penting, yang umum dilakukan oleh negara-negara produsen agar dapat berproduksi dan berperan lebih besar dalam pasar pelet kayu, yang harus diperhatikan oleh Indonesia, yaitu: (1) negara harus mampu menunjukkan kepastian suplai (sebagai bukti keberlanjutan), (2) kualitas, (3) keandalan dan kekuatan keuangan, dan (4) harga yang kompetitif.

Pasar Wood Pellet Asia masih dikuasai oleh Vietnam dengan kontribusi kepada pasar Wood Pellet dunia mencapai 25\%, Malaysia sekitar 7\%, sedangkan Indonesia masih sekitar $2 \%$. Hal ini berbanding terbalik dengan luas hutan di Indonesia yang merupakan terbesar di dunia. Pemerintah (Kementerian Energi dan Sumber Daya Mineral) menargetkan pemakaian energi terbarukan pada tahun 2025 mencapai 23\% artinya kebutuhan akan wood pellet di dalam negeri saja masih terbuka lebar, apalagi kebutuhan dunia.

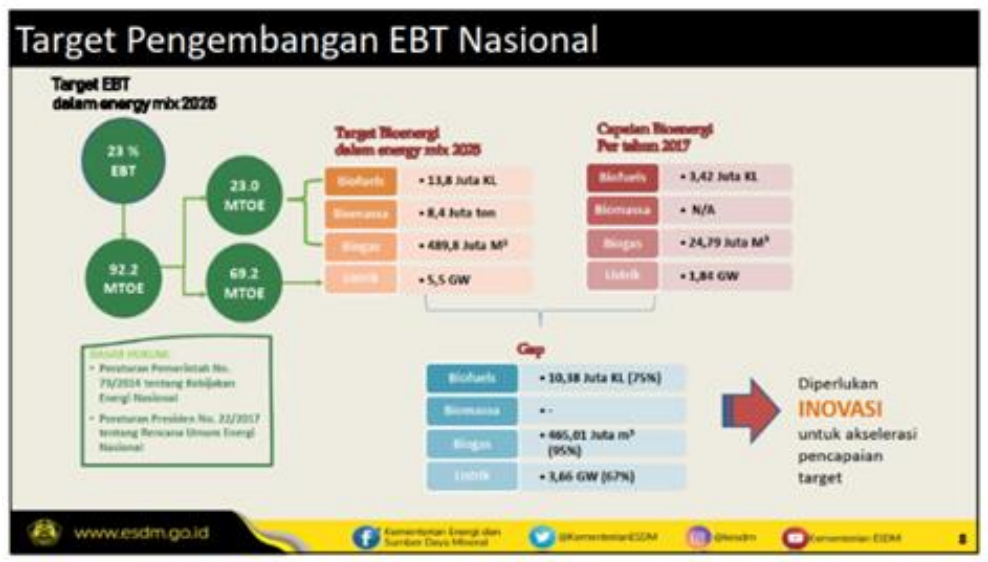

Gambar 2. Target Pengembangan EBT Nasional 
Salah satu metode yang dapat dipilih untuk melakukan perencanaan yang strategis dalam suatu organisasi adalah analisis SWOT (Susilowati et al., 2020). Analisis SWOT dapat digunakan untuk membangun strategi yang kompetitif dari sebuah organisasi. Menurut pendekatan sistem, organisasi merupakan keutuhan yang berinteraksi dengan lingkungan, serta terdiri dari sub-sub sistem. Berdasarkan dari pengertian tersebut, sebuah organisasi terdapat pada dua lingkungan, satu berada dalam dirinya sendiri (internal) dan yang lainnya berada di luar (eksternal). Oleh sebab itu, telah menjadi sebuah kebutuhan untuk menganalisis lingkungan-lingkungan tersebut untuk menciptakan suatu manajemen strategis. Proses ini dilakukan dengan cara memeriksa organisasi dan lingkungannya, yang disebut dengan analisis SWOT. SWOT merupakan singkatan dari Strength, Weakness, Opportunity, dan Threat. Strength yang berarti kekuatan, serta Weakness yang berarti kelemahan merupakan faktor internal yang dimiliki oleh suatu organisasi, sedangkan Opportunity yang berarti peluang serta Threat yang berarti ancaman merupakan faktor eksternal yang dimiliki organisasi. Analisis SWOT diterapkan dengan melakukan perbandingan di antara faktor internal dan juga faktor eksernal organisasi. Dalam melakukan perencanaan strategis, terdaapt empat jenis strategi yang dapat dipilih sebagai solusi. Keempat strategi yang dimaksud adalah (Tyas dan Chrisnawahyudi, 2017):

a. SO (Strength-Opportunity), penggunaan kekuatan di dalam organisasi untuk memanfaatkan peluang eksternal merupakan poin dari strategi ini.

b. WO (Weakness-Opportunity), perbaikan kelemahan di dalam organisasi dengan memanfaatkan peluang eksternal yang ada merupakan poin dari strategi ini.

c. ST (Strength-Threat), penggunaan kekuatan organisasi untuk menghindari ancaman merupakan poin dari strategi ini.

d. WT (Weakness-Threat), organisasi akan mengalami kesulitan apabila berada pada posisi ini, namun tidak menjadi tidak mungkin bagi organisasi untuk mampu mengatasinya.

Dalam melakukan perencanaan strategis pada bisnis, terdapat metode lain yang dapat digunakan, salah satunya adalah analisis BCG. Analisis ini diterapkan dengan mengklasifikasikan produk berdasarkan pada nilai tingkat pertumbuhan pasar serta nilai pangsa pasar relatifnya di dalam suatu matriks, yang disebut dengan matriks BCG.

Di dalam matriks BCG terdapat empat klasifikasi dari produk, sebagaimana menggunakan nilai tingkat pertumbuhan pasar (sumbu Y) dan juga pangsa pasar relatif (sumbu X) sebagai dasarnya. Keempat klasifikasi produk tersebut terlampir di bawah ini:

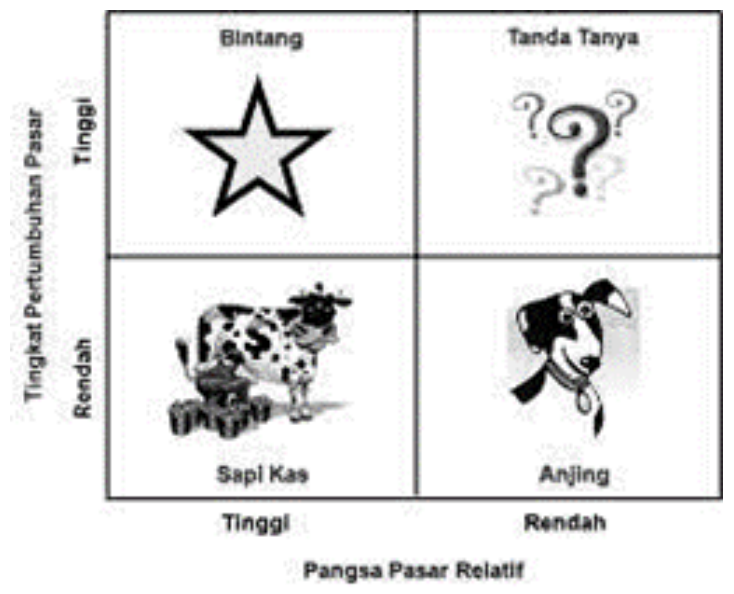

Gambar 3. Matriks BCG

\section{Metode Penelitian}

Penelitian ini memuat deskripsi yang berkaitan dengan sifat dan juga fakta dari objek penelitian yang diteliti, sehingga dapat dikategorikan sebagai jenis penulisan deskriptif. Penuturan pemecahan masalah dilakukan dengan berdasar pada data-data yang telah dikumpulkan. Penyajian, analisis, serta interpretasi dari data-data merupakan hal-hal yang diusahakan dalam penulisan jenis ini.

Perolehan data berasal dari berbagai dokumen-dokumen atau literatur-literatur online, seperti jurnal, e-book, dll. Dengan demikian, perolehan data bersumber pada data-data sekunder.

Penelitian ini memilih studi pustaka (Literature Review) sebagai metode pengumpulan data. Pemilihan metode ini bertujuan untuk mendapatkan informasi-informasi lebih ke arah penelitian yang serupa serta relevan untuk 
dijadikan referensi, dengan cara membaca, mempelajari, dan mendalami literatur-literatur. Hal ini dimaksudkan agar penulis lebih memahami data-data yang terkait dalam pembuatan penelitian ini.

Pengolahan dan juga analisis data pada penelitian ini menggunakan metode analisis BCG dan juga SWOT. Untuk analisis BCG terdapat dua data yang diperlukan, yakni nilai tingkat pertumbuhan pasar, serta nilai pangsa pasar relatif. Kedua data yang diperlukan tersebut diperoleh dengan melakukan perhitungan. Persamaan (1) digunakan untuk memperoleh nilai tingkat pertumbuhan pasar adalah:

Keterangan :

$$
T P P=\frac{V P_{N}-V P_{N-1}}{V P_{N-1}} \times 100 \%
$$

TPP = Tingkat Pertumbuhan Pasar

VP N = Volume penjualan tahun terakhir

VP N-1 = Volume penjualan tahun sebelumnya

Sedangkan, Persamaan (2) untuk memperoleh nilai pangsa pasar relatif adalah:

Keterangan :

$$
P P R=\frac{V P_{N}}{V P P_{N}}
$$

PPR = Pangsa Pasar Relatif

$\mathrm{VPN}=$ Volume penjualan tahun terakhir

VPPN = Volume penjualan tahun terakhir pesaing

Nilai tingkat pertumbuhan pasar dan juga pangsa pasar relatif yang telah diperoleh akan dimasukkan ke dalam matriks BCG, dengan koordinat sumbu x berdasarkan pada nilai pangsa pasar relatif, dan koordinat sumbu y berdasarkan pada nilai tingkat pertumbuhan

Pengolahan data untuk analisis SWOT memerlukan data kekuatan, kelemahan, peluang, dan juga ancaman dari industri biomassa pelet kayu di Indonesia. Semua data yang diperoleh, kemudian akan disusun dalam matriks SWOT. Setelah mengetahui kondisi kekuatan, kelemahan, peluang, dan ancaman dari industri terkait, penulis akan merancang strategi-strategi yang yang relevan dengan kondisi industri biomassa pelet kayu di Indonesia.

\subsection{Data Penelitian}

Pada penelitian ini, terdapat beberapa literatur yang dijadikan sebagai referensi utama, yaitu:

a. $\quad$ E-book dengan judul “Pellet Kayu Energi Hijau Masa Depan” Edisi Juli 2018 karya Rudianto Amirta.

b. Jurnal dari Jurnal Ilmu Kehutanan 12 (2018) dengan judul "Kajian Peningkatan Potensi Ekspor Pelet Kayu Indonesia sebagai Sumber Energi Biomassa yang Terbarukan” karya Victor Tulus Pangapoi Sidabutar

c. Bioenergy Europe Statistical Report 2019 yang diterbitkan oleh European Pellet Council

Tabel 1. Data Produksi Pelet Kayu 2017 dan 2018 di berbagai negara

\begin{tabular}{|c|c|c|c|c|c|c|}
\hline & \multicolumn{3}{|c|}{2017} & \multicolumn{3}{c|}{2018} \\
\hline $\begin{array}{c}\text { Jumlah } \\
\text { pabrik } \\
\text { produksi } \\
\text { yang } \\
\text { beroperasi }\end{array}$ & $\begin{array}{c}\text { Kapasitas } \\
\text { produksi } \\
\text { (ton) }\end{array}$ & $\begin{array}{c}\text { Produksi } \\
\text { aktual } \\
\text { (ton) }\end{array}$ & $\begin{array}{c}\text { Jumlah } \\
\text { pabrik } \\
\text { produksi } \\
\text { yang } \\
\text { beroperasi }\end{array}$ & $\begin{array}{c}\text { Kapasitas } \\
\text { produksi } \\
\text { (ton) }\end{array}$ & $\begin{array}{c}\text { Produksi } \\
\text { aktual } \\
\text { (ton) }\end{array}$ \\
\hline CA & 40 & 3.800 .000 & 2.500 .000 & 44 & 4.168 .000 & 2.700 .000 \\
\hline US & 145 & 11.838 .864 & 7.900 .000 & 82 & 11.995 .034 & 8.200 .000 \\
\hline BR & 16 & 848.800 & 470.900 & 19 & 1.210 .000 & 428.000 \\
\hline CL & 17 & 112.400 & 77.718 & 20 & 138.600 & 121.412 \\
\hline CN & 2.089 & 31.343 .283 & 16.800 .000 & 2.240 & 34.502 .394 & 20.250 .000 \\
\hline ID & 8 & 355.000 & 119.730 & n.a. & n.a. & 224.167 \\
\hline JP & 147 & n.a. & 126.532 & n.a. & n.a. & n.a. \\
\hline KR & n.a. & n.a. & n.a. & n.a. & n.a. & n.a. \\
\hline MY & 25 & 850.000 & 413.035 & n.a. & n.a. & 596.025 \\
\hline TH & 16 & 832.000 & 95.548 & n.a. & n.a. & 317.029 \\
\hline VN & n.a. & n.a. & 1.646 .918 & n.a. & n.a. & 2.560 .036 \\
\hline AU & 9 & 300.000 & 200.000 & 10 & 400.000 & 130.000 \\
\hline NZ & 3 & 270.000 & 50.000 & 3 & 155.000 & 75.000 \\
\hline
\end{tabular}

Keterangan:

$\mathrm{CA}=$ Canada

US $=$ United States of America

$\mathrm{BR}=$ Brazil

$\mathrm{CL}=$ Chile 


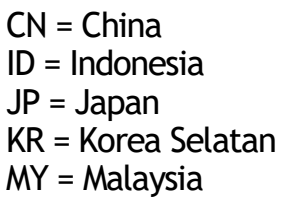

\subsection{Alur Penelitian}

Gambar 4 menyajikan alur dari penelitian ini.

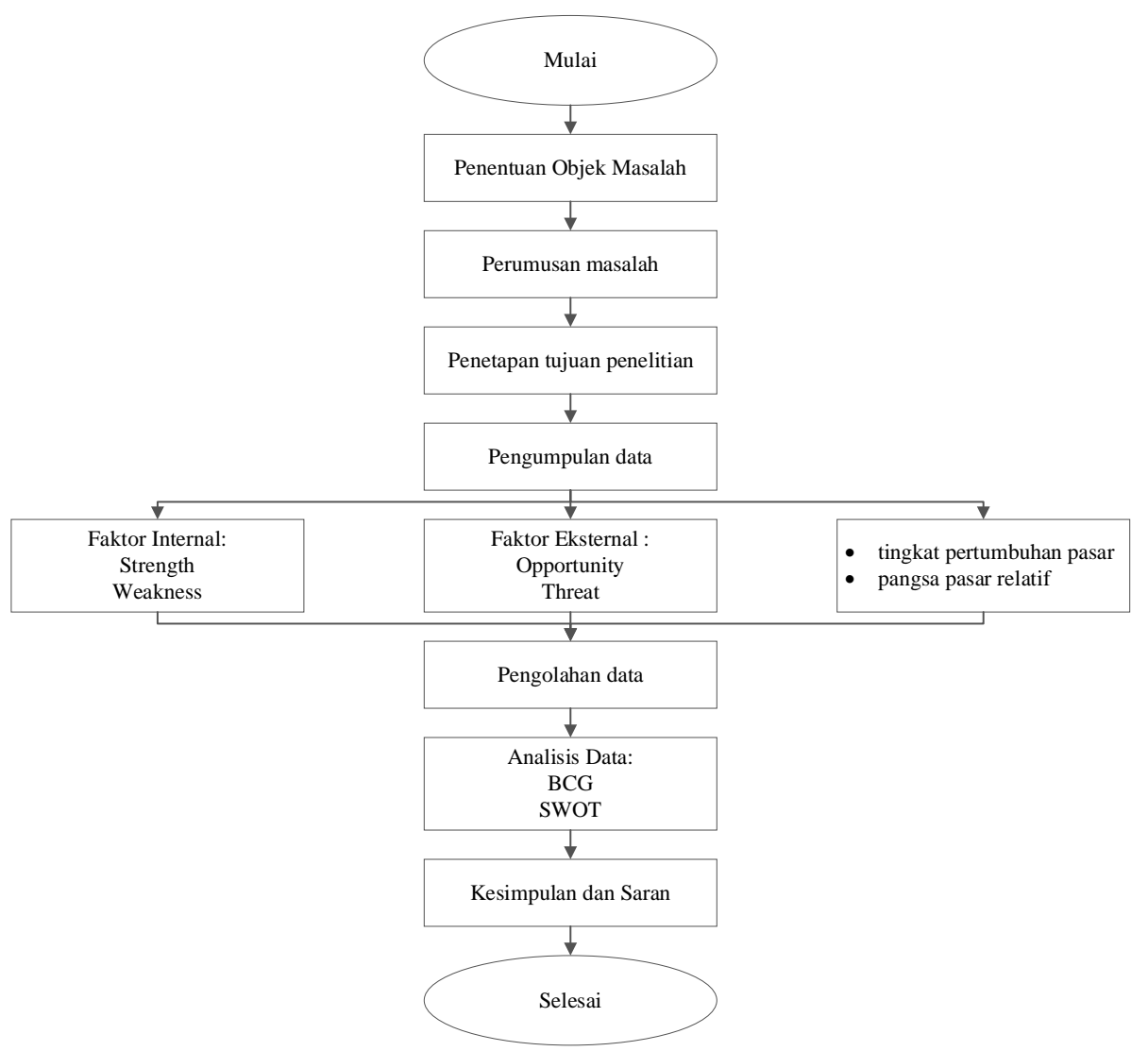

Gambar 4. Alur Penelitian

\section{Hasil dan Pembahasan}

\subsection{Analisis BCG}

Penelitian ini menggunakan data produksi Vietnam sebagai negara pesaing, sehingga diperoleh:

Tabel 2. Data untuk pengolahan data analisis BCG

\begin{tabular}{|c|c|c|}
\hline & Produksi 2017 & Produksi 2018 \\
\hline Indonesia & 119.730 ton & 224.167 ton \\
\hline $\begin{array}{c}\text { Vietnam } \\
\text { (pesaing) }\end{array}$ & 1.646 .918 ton & 2.560 .036 ton \\
\hline
\end{tabular}

Perhitungan Tingkat Pertumbuhan Pasar (TPP)

$$
\begin{gathered}
T P P=\frac{\text { Volume Produksi } i_{2018}-\text { Volume Produksi }_{2017}}{\text { Volume Produksi }_{2017}} \times 100 \% \\
T P P=\frac{224.167-119.730}{119.730} \times 100 \% \\
T P P=87,2270943 \%
\end{gathered}
$$

Perhitungan Pangsa Pasar Relatif (PPR) adalah sebagai berikut:

$$
P P R=\frac{\text { Volume Produksi } 2018}{\text { Volume Produksi Pesaing } 2018} \times 100 \%
$$




$$
\begin{gathered}
P P R=\frac{224.167}{2.560 .036} \times 100 \% \\
P P R=0,087564003
\end{gathered}
$$

Berdasarkan perhitungan diperoleh secara berturut untuk nilai tingkat pertumbuhan pasar dan pangsa pasar relatif industri biomassa pelet kayu Indonesia sebesar 87,2270943\% dan 0,087564003. Dengan kedua nilai tersebut, maka posisi industri tersebut pada matriks BCG adalah:

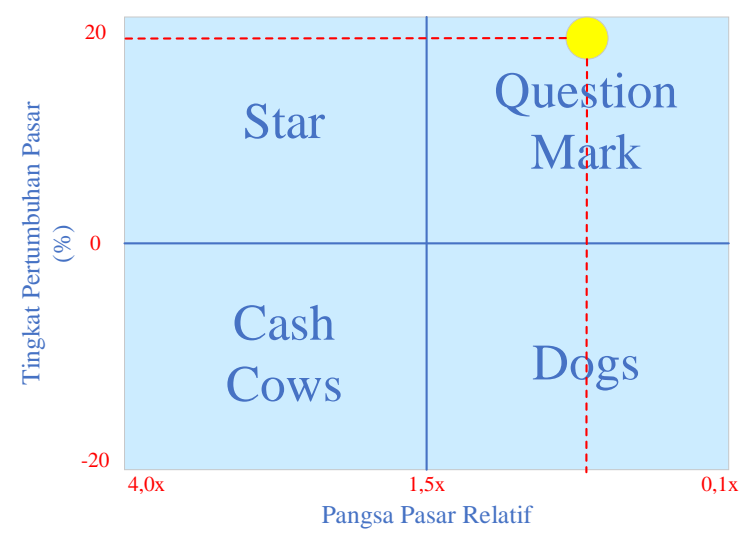

Gambar 5. Posisi Industri Pelet Kayu Indonesia pada matriks BCG

Diketahui bahwa industri pelet kayu Indonesia terletak pada posisi "Question Mark". Question marks merupakan kondisi di mana suatu bisnis memiliki nilai pangsa pasar yang rendah, tetapi berada pada pasar yang berkembang. Hal ini mengindikasikan bahwa industri pelet kayu Indonesia memiliki pasar yang sangat berpotensi untuk berkembang di masa yang akan datang. Namun, produk pelet kayu yang ditawarkan ataupun dijual oleh Indonesia kalah bersaing dengan negara-negara lain, yang notabene sudah menjadi pemain utama produsen pelet kayu baik di Asia ataupun dunia. Hal ini mengakibatkan pangsa pasar industri pelet kayu Indonesia menjadi rendah.

Indonesia belum dapat memanfaatkan peluang-peluang, baik secara internal ataupun eksternal, yang berhubungan dengan industri pelet kayu. Hal tersebut yang dapat mengakibatkan daya saing Indonesia di industri pelet kayu dunia lebih rendah apabila dibandingkan dengan negara-negara lain. Indonesia memiliki kekayaan alam yang sangat mendukung proses produksi pelet kayu, baik dari sisi ketersediaan lahan dan juga ketersediaan bahan baku. Indonesia belum memanfaatkan hal ini secara maksimal. Dengan ketidakmaksimalan pemanfaatan peluang internal yang ada, tentu hal ini dapat menghambat Indonesia untuk menggapai peluangpeluang eksternal yang sangat menentukan nilai pangsa pasar relatif unit bisnis, karena berkaitan dengan pihak pesaing (competitor).

\subsection{Analisis SWOT}

\subsubsection{Strength (Kekuatan)}

- Indonesia memiliki sumber alam yang besar, wilayah hutan dan lahan terdegradasi yang lebih luas apabila dibandingkan dengan Vietnam (pesaing)

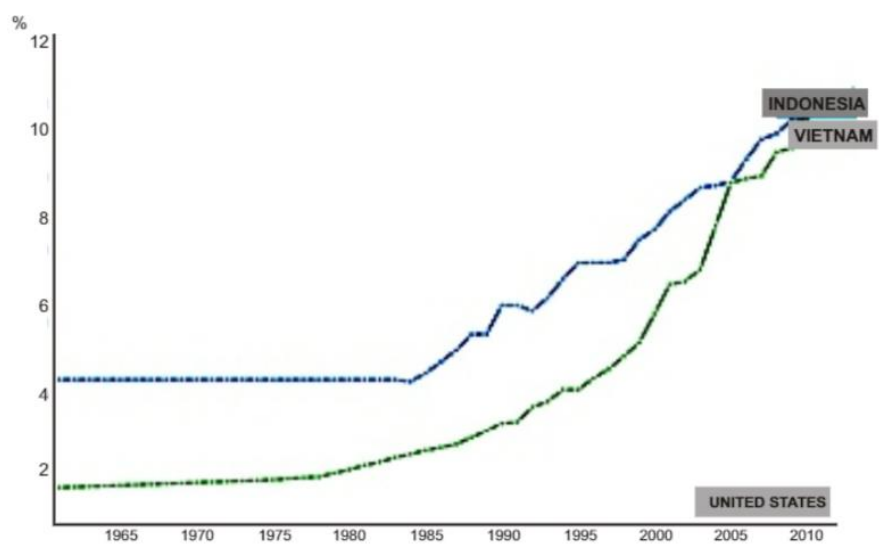

Gambar 6. Perbandingan luas lahan tanaman Indonesia dengan Vietnam dan Amerika (World Bank,2016) 
Korea Selatan telah memulai impor pelet kayu dengan jumlah yang bervariasi dari Indonesia sejak tahun 1988 menurut laporan ITPC Busan yang diterbitkan pada tahun 2014

- Terdapat banyak tanaman yang dapat menjadi sumber bahan baku untuk membuat pelet kayu di Indonesia

- Pemerintah Indonesia mengeluarkan Permen LHK No.P.83/MENHLK/SETJEN/ KUM.10/2016 tentang Perhutanan Sosial untuk memudahkan masyarakat dalam mengurus legalitas untuk bahan baku kayu

- Indonesia diketahui merupakan produsen kelapa sawit terbesar dengan total produksi yang mencapai 23 juta ton/tahun. Produksi dalam jumlah besar ini menghasilkan limbah-limbah yang dapat dimanfaatkan menjadi sumber bahan baku untuk pembuatan pelet kayu.

\subsubsection{Weakness (Kelemahan)}

- Faktor biofisik dapat menghambat aktivitas produksi, seperti kemiringan tanah, sulitnya akses, ketidaksuburan lahan dan kondisi lainnya

- Banyak produsen pelet kayu lokal yang lebih mengutamakan bidang ekspor, dikarenakan target penggunaan energi biomassa terbarukan hanya sebesar 5\% di Indonesia berdasarkan pada Peraturan Presiden No.5 Tahun 2006

- Penerapan SVLK (Sistem Verifikasi dan Legalitas Kayu) pada UMKM di Indonesia masih tergolong cukup sulit dikarenakan tingginya biaya, pengetahuan pengelola UMKM yang belum memadai, serta terbatasnya jumlah lembaga verifikasi SVLK.

Indonesia belum mampu mempertahankan kualitas dari pelet kayu yang ditawarkan ke pihak importir. Hal ini terjadi pada ekspor pelet kayu Indonesia ke Korea Selatan. Jumlah ekspor kerap mengalami penurunan yang drastis pada tahun 1996 sampai dengan 2006.

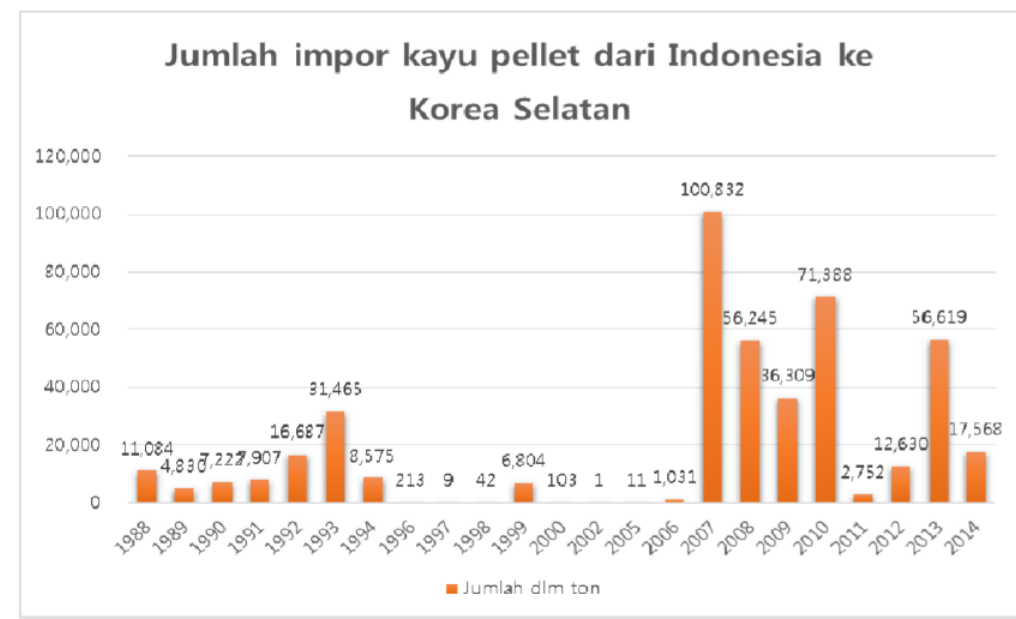

Gambar 6. Ekspor Pelet Kayu Indonesia ke Korea tahun 1988-2014

\subsubsection{Opportunity (Peluang)}

- Menurut Roos (2012), konsumsi energi di dunia akan meningkat pada tahun 2035

- Permintaan pelet kayu di Asia juga akan meningkat terutama pada bidang industri energi pemanas (Roos 2012)

- Dalam rangka pengurangan emisi gas rumah kaca, maka diterbitkan kebijakan Protokol Paris yang menekankan penggunaan energi terbarukan

\subsubsection{Threat (Ancaman)}

- Daya saing ekspor Indonesia kalah apabila dibandingkan dengan Vietnam. Vietnam lebih mampu menguasai pasar.

- Harga jual yang ditawarkan pihak pesaing, yakni Vietnam, lebih rendah apabila dibandingkan dengan Indonesia. Hal ini tentunya dapat mengakibatkan importir lebih memilih Vietnam sebagai pihak eksportir nya. 
Tabel 3. Kinerja daya saing ekspor pelet kayu ke Korea Selatan di 2015

\begin{tabular}{|c|c|c|c|c|c|c|c|c|c|}
\hline \multicolumn{10}{|c|}{ Indikator Perdagangan } \\
\hline $\begin{array}{c}\text { Negara } \\
\text { pengekspo } \\
r\end{array}$ & $\begin{array}{c}\text { Nilai } \\
\text { impor } \\
\text { tahun } \\
2015 \\
\text { (dala } \\
\text { m ribu } \\
\text { USD) }\end{array}$ & $\begin{array}{l}\text { Neraca } \\
\text { perdaga } \\
\text { gan } \\
2015 \\
\text { (dalam } \\
\text { ribu } \\
\text { USD) }\end{array}$ & $\begin{array}{c}\text { Bagian } \\
\text { dalam } \\
\text { impor } \\
\text { Korea } \\
\text { Selatan } \\
(\%)\end{array}$ & $\begin{array}{c}\text { Kuantitas } \\
\text { impor di } \\
2015 \text { (ton) }\end{array}$ & $\begin{array}{c}\text { Nilai } \\
\text { unit } \\
\text { (USD/un } \\
\text { it) }\end{array}$ & $\begin{array}{c}\text { Pertumbu } \\
\text { han nilai } \\
\text { impor } \\
\text { antara } \\
2011-2015 \\
\text { (\%) }\end{array}$ & $\begin{array}{c}\text { Pertumbu } \\
\text { han } \\
\text { kuantitas } \\
\text { impor } \\
\text { antara } \\
2011-2015 \\
\text { (\%) }\end{array}$ & $\begin{array}{l}\text { Pertumb } \\
\text { uhan } \\
\text { nilai } \\
\text { impor } \\
\text { antara } \\
2014- \\
2015(\%)\end{array}$ & $\begin{array}{c}\text { Total } \\
\text { pertumbu } \\
\text { han nilai } \\
\text { ekspor } \\
\text { negara } \\
\text { mitra } \\
\text { antara } \\
2011- \\
2015(\%)\end{array}$ \\
\hline Total & $\begin{array}{c}176.96 \\
3\end{array}$ & $\begin{array}{c}- \\
176.963\end{array}$ & 100 & 1.470 .684 & 120 & 124 & 120 & -45 & 15 \\
\hline Vietnam & $\begin{array}{c}114.90 \\
0\end{array}$ & $\begin{array}{c}- \\
114.900\end{array}$ & 64,9 & 1.022 .809 & 112 & 139 & 133 & -7 & 188 \\
\hline Malaysia & 18.762 & -18.762 & 10,6 & 153.959 & 122 & 111 & 110 & -31 & 39 \\
\hline Kanada & 16.019 & -16.019 & 9,1 & 87.743 & 183 & 249 & 263 & -76 & 0 \\
\hline Rusia & 11.296 & $\begin{array}{l}-11.296 \\
\end{array}$ & 6,4 & 84.070 & 134 & 103 & 97 & 97 & 4 \\
\hline Indonesia & 7.766 & -7.766 & 2,7 & 65.686 & 118 & 138 & 124 & 30 & 13 \\
\hline
\end{tabular}

Berdasarkan data kekuatan, kelemahan, peluang, serta ancaman pada industri pelet kayu Indonesia yang disajikan, dengan demikian rancangan strategi yang dapat dibuat seperti tercantum pada Tabel 4.

Tabel 4. Strategi SWOT

\begin{tabular}{|c|c|c|}
\hline & $\begin{array}{l}\text { Strength } \\
\text { 1. Indonesia memiliki lahan hutan } \\
\text { yang luas } \\
\text { 2. Indonesia telah beberapa kali } \\
\text { melakukan ekspor ke Korea } \\
\text { Selatan } \\
\text { 3. Indonesia memiliki varian } \\
\text { tanaman untuk bahan baku } \\
\text { 4. Pemerintah a memberikan } \\
\text { dukungan untuk legalitas bahan } \\
\text { baku } \\
\text { 5. Indonesia dapat memanfaatkan } \\
\text { limbah kelapa sawit }\end{array}$ & $\begin{array}{l}\text { Weakness } \\
\text { 1. Kemiringan lahan dan } \\
\text { kesuburan tanah menjadi } \\
\text { faktor penentu } \\
\text { 2. Produsen lokal lebih } \\
\text { mengutamakan pasar ekspor } \\
\text { 3. Banyak tantangan dalam } \\
\text { Penerapan SVLK pada UKM } \\
\text { 4. Ekspor Indonesia menurun } \\
\text { dikarenakan tidak mampu } \\
\text { memenuhi standar kualitas } \\
\text { importir }\end{array}$ \\
\hline $\begin{array}{l}\text { Opportunity } \\
\text { 1. Diperkirakan akan ada } \\
\text { kenaikan konsumsi energi } \\
\text { dunia pada tahun } 2035 \\
\text { 2. Permintaan pelet kayu Asia } \\
\text { juga meningkat } \\
\text { 3. Terdapat kebijakan } \\
\text { penggunaan energi terbarukan } \\
\text { dan pengurangan emisi gas } \\
\text { rumah kaca (protokol Paris) }\end{array}$ & $\begin{array}{l}\text { Strategi SO: } \\
\text { 1. Memaksimalkan sumber daya } \\
\text { alam yang dimiliki, dari mulai } \\
\text { ketersediaan lahan serta } \\
\text { ketersediaan tanaman yang ada } \\
\text { untuk memenuhi energi nasional } \\
\text { serta pasar internasional } \\
\text { 2. Mendukung kebijakan protokol } \\
\text { Paris, sehingga dapat menjalin } \\
\text { kerja sama dengan negara-negara } \\
\text { lain yang memiliki visi yang sama }\end{array}$ & $\begin{array}{l}\text { Strategi WO: } \\
\text { 1. Meningkatkan ekspor pelet } \\
\text { kayu ke negara-negara dengan } \\
\text { konsumsi pelet kayu yang } \\
\text { tinggi } \\
\text { 2. Mempersiapkan pengusaha- } \\
\text { pengusaha UKM produksi pelet } \\
\text { kayu untuk, baik secara } \\
\text { pengetahuan maupun } \\
\text { teknologi, untuk menghadapi } \\
\text { kenaikan konsumsi energi } \\
\text { dunia }\end{array}$ \\
\hline $\begin{array}{l}\text { Threat } \\
\text { 1. Indonesia kalah dalam hal } \\
\text { daya saing ekspor dengan } \\
\text { negara lain, contoh: Vietnam } \\
\text { 2. Harga pelet kayu Indonesia } \\
\text { lebih mahal jika dibandingkan } \\
\text { Vietnam }\end{array}$ & $\begin{array}{l}\text { Strategi ST: } \\
\text { 1. Menggunakan bahan baku pelet } \\
\text { kayu dari limbah-limbah } \\
\text { pertanian ataupun perkebunan, } \\
\text { seperti kelapa sawit untuk dapat } \\
\text { menekan harga pelet kayu yang } \\
\text { dijual di pasar lokal dan } \\
\text { internasional }\end{array}$ & $\begin{array}{l}\text { Strategi WT: } \\
\text { 1. Mempertahankan kualitas } \\
\text { pelet kayu yang ditawarkan } \\
\text { kepada pelanggan } \\
\text { 2. Membuat kebijakan untuk } \\
\text { mendukung produsen pelet } \\
\text { kayu lokal agar dapat bersaing } \\
\text { di dalam dan luar negeri }\end{array}$ \\
\hline
\end{tabular}

Telah diketahui bahwa Industri pelet kayu Indonesia terletak pada posisi Question Mark, dikarenakan belum dapat memanfaatkan peluang-peluang bisnis yang ada dengan maksimal, baik secara internal dan eksternal. Dalam analisis SWOT, peluang internal berkaitan dengan strength dari unit bisnis, dan peluang eksternal berkaitan dengan opportunity dari unit bisnis tersebut. Dengan demikian, strategi yang cocok untuk digunakan pada industri pelet kayu Indonesia adalah Strategi SO(Strength-Opportunity), yaitu: 
1. Memaksimalkan sumber daya alam yang dimiliki, dari mulai ketersediaan lahan serta ketersediaan tanaman yang ada untuk memenuhi energi nasional serta pasar internasional

2. Mendukung kebijakan protokolo Paris, sehingga dapat menjalin kerja sama dengan negara-negara lain yang memiliki visi yang sama

\section{Kesimpulan}

Kekuatan industri biomassa wood pellet di Indonesia adalah Indonesia memiliki lahan hutan yang luas, Indonesia telah beberapa kali melakukan ekspor ke Korea Selatan, Indonesia memiliki varian tanaman untuk bahan baku, pemerintah memberikan dukungan untuk legalitas bahan baku, serta Indonesia dapat memanfaatkan limbah kelapa sawit sebagai bahan baku. Kelemahan industri biomassa wood pellet di Indonesia adalah kemiringan lahan dan kesuburan tanah menjadi faktor penentu, produsen lokal lebih mengutamakan pasar ekspor, banyak tantangan dalam penerapan SVLK pada UKM, serta ekspor Indonesia menurun dikarenakan tidak mampu memenuhi standar kualitas importir. Peluang industri biomassa wood pellet di Indonesia adalah diperkirakan akan ada kenaikan konsumsi energi dunia pada tahun 2035, permintaan pelet kayu Asia juga meningkat, serta terdapat kebijakan penggunaan energi terbarukan dan pengurangan emisi gas rumah kaca (protokol Paris). Ancaman industri biomassa wood pellet di Indonesia adalah Indonesia kalah dalam hal daya saing ekspor dengan negara lain, contoh: Vietnam serta harga pelet kayu Indonesia lebih mahal jika dibandingkan Vietnam.

Industri biomassa wood pellet di Indonesia terletak pada posisi "Question Marks" pada matriks BCG, yang berarti bahwa industri ini berada pada pasar yang berkembang, namun memiliki pangsa pasar yang rendah, sehingga rancangan strategi yang cocok untuk pengembangan industri biomassa wood pellet di Indonesia adalah strategi SO (Strength-Opportunity), yaitu; memaksimalkan sumber daya alam yang dimiliki, dari mulai ketersediaan lahan serta ketersediaan tanaman yang ada untuk memenuhi energi nasional serta pasar internasional, serta mendukung kebijakan protokol Paris, sehingga dapat menjalin hubungan kerja sama dengan negara-negara yang juga mendukung kebijakan tersebut.

\section{DAFTAR PUSTAKA}

1. Amirta, R. (2018). Pellet Kayu Energi Hijau Masa Depan. Samarinda: Mulawarman University PRESS.

2. Astana, S., Hani, A., Edom, W., Nuroniah, H. S., Lelana, N. E., Kurniasari, D. R., \& Bangsawan, I. (2016). Kiat Berbisnis Sengon: Tanam Sekali, Untung Berkali-kali. Bogor: Forda Press.

3. Bank, T. W. (2016). World Bank Open Data. Retrieved from The World Bank: https: / / data. worldbank.org/indicator/AG.LND.CROP.ZS?gclid=CKDS8LKhw9ACFdCHaAodRWoD4

4. Banten, D. P. (2018, Mei 24). DLHK Provinsi Banten. Retrieved Juni 22, 2021, from https://dlhk.bantenprov.go.id/read/article/476/Energi-Baru-dan-TerbarukanPelet-KayuWood-Pellet.html

5. CIFOR. (2016, Mei 31). CIFOR. Retrieved Juni 22, 2021, from https://www.cifor.org/knowledge/publication/6172/

6. Council, E. P. (2019). Bioenergy Europe Statistical Report.

7. D. J. (2016). Buku Pedoman Investasi Bioenergi di Indonesia.

8. Janiah, S. (2019). STRATEGIC MANAGEMENT EFE-IFE MATRIX, SWOT ANALYSIS, COMPETITIVE PROFIL MATRIX (CPM) DAN BCG MATRIX PADA PT YAMAHA. Jurnal Ekonomi dan Manajemen Sistem Informasi, 1(2), 188-196.

9. Klepacka, A. M., \& Florkowski, J. W. (2019). The Wood Pellet Sector: Barriers to Growth and Opinions of Manufacturers in Poland . Scientific Journal Warsaw University of Life Sciences, 19(4), 9-18.

10. Laksana, T. N., \& Waluyo, M. (2021). ANALISIS STRATEGI PEMASARAN DENGAN METODE SWOT DAN BCG DI PT. XYZ. Juminten, 2(2), 96-107. 
DOI: https://doi.org/10.33021/jie.v6i2.1588 JIE, Vol. 6, No.2, September 2021: 151-161

11. Manik, R. G. (2018). IDENTIFIKASI STRATEGI PERUSAHAAN MENGGUNAKAN ANALISIS SWOT DAN MATRIKS BCG PADA PT. TAMAN WISATA CANDI BOROBUDUR, PRAMBANAN DAN RATU BOKO. Yogyakarta: Universitas Pembangunan Nasional "Veteran" Yogyakarta.

12. Mulyana, T., \& Firdaus, R. (2017). Analisis Strategi Pemasaran PT. Vivo Communication. Jurnal Wacana Ekonomi, 17(1), 53-65.

13. Mustamu , S., Hermawan, \& Pari, G. (2018). KARAKTERISTIK BIOPELET DARI LIMBAH PADAT KAYU PUTIH DAN GONDORUKEM. Jurnal Penelitian Hasil Hutan, 36(13), 191-204.

14. Qian, F., Chyang, C., Huang, K., \& Tso, J. (2011). Combustion and NO emission of high nitrogen content biomass in a pilot-scale vortexing fluidized bed combustor. Bioresource Technology, 102(2), 1892-1898.

15. Roos, J., \& Brackley, A. (2012). The Asian Wood. United States of America: The Forest Service of United States Department of Agriculture.

16. Rosadi, S. D., \& Utami, B. (2018). Perencanaan Strategi Pemasaran Melalui Metode SWOT dan BCG pada LBB Sony Sugema College Mojosari. Bisman (Bisnis dan Manajemen): The Journal of Business and Management, 1(1), 1-19.

17. Setiawan, A. (2007). Memanfaatkan Kotoran Ternak Solusi Masalah Lingkungan dan Pemanfaatan Energi Alternatif. Jakarta: Penebar Swadaya.

18. Sidabutar, V. P. (2018). Kajian Peningkatan Potensi Ekspor Pelet Kayu Indonesia sebagaiSumber Energi Biomassa yang Terbarukan. Jurnal Ilmu Kehutanan, 12(1), 99-116.

19. Subhan, A., \& Peratiwi, M. (2017). ANALISIS STRATEGI PEMASARAN PRODUK DENGAN METODE ANALISIS MATRIK BCG, SWOT DAN BENCHMARKING PADA PERUSAHAAN RUBBY HIJAB. Jurnal Industrial Services, 3(1C), 311-316.

20. Susilowati, A., Yusuf, A., Amanda, B. F., Wahyuni, A., \& Sanjaya, V. (2020). ANALISIS STRATEGI KEUNGGULAN BERSAING DENGAN PENDEKATAN ANALISIS SWOT DAN METODE QSPM (STUDI KASUS MURBAY KONVEKSI). Jurnal Syntax Admiration , 1(3), 124-129.

21. Tyas, S. K., \& Chriswahyudi, C. (2017). PERENCANAAN STRATEGI PEMASARAN DENGAN PENDEKATAN MATRIK IE, SWOT DAN AHP UNTUK MENDAPATKAN ALTERNATIF STRATEGI PRIORITAS. PROSIDING SEMNASTEK 2017, 1-9.

22. Walker, J. (2006). Primary Wood Processing: Principles and Practice. Springer Science \& Business Media, 606, 538-539.

23. Yilmaz, S., \& Selim, H. (2013). A review on the methods for biomass to energy conversion systems design. Renewable and Sustainable Energy Reviews, 25, 420-430. 